\title{
MORPHOLOGICAL AND PHYSIOLOGICAL RESPONSES OF CROTON BONPLANDIANUM BAILL. TO AIR POLLUTION
}

\author{
M. Saquib ${ }^{1}$, A. Ahmad ${ }^{2}$ and K. Ansari \\ ${ }^{\mathbf{1}}$ Department of Biological Sciences, Faculty of Science, Adamawa State University, Mubi, Adamawa \\ State, Nigeria \\ ${ }^{2}$ Department of Botany, Faculty of Science, Hamdard University, New Delhi, India \\ *E-mail: mohammadaqib@hotmail.com
}

\begin{abstract}
The air pollution stress around the thermal power plant lead to the significant reduction in size and biomass of root and shoot, photosynthetic rate, stomatal conductance, intercellular $\mathrm{CO}_{2}$ concentration, photosynthetic pigments and photosynthetic area of Croton bonplandianum. The resulting stresses of air pollution and reduced foliage further affected the over all morphology and physiology of the plant. Root biomass and chlorophyll a showed maximum reduction than any other selected parameters studied in the stressed area. Chlorophyll a was found to be four and half times more sensitive to air pollutants than carotenoids.
\end{abstract}

Key words: Air pollution, thermal power plant, morphology and physiology, C. bonplandianum.

\section{INTRODUCTION}

Air pollution, mainly due to the gaseous emission of industries, thermal power station, automobiles and the domestic combustion, is causing a number of diseases and deformities in living beings, particularly in metropolitan cities. The current widespread use of coal in thermal power plant has contributed sizeably to degradation of the atmosphere. About 80 percent of electricity in India is generated by thermal power plants. The thermal power plants running on sulphur-rich low grade bituminous coal emit enormous amounts of the oxides of sulphur, nitrogen and carbon, various other gases in small quantities, and particulates. These pollutants caused injury and damage to plants and plant parts in a number of ways (Ghouse and Saquib 1986, Yunus and Iqbal 1996, Iqbal et al. 2000, Saquib
2008, 2009, Iqbal et al. 2010). The extent of injury depends on concentration of gases, fumigation frequency, duration of exposure and the prevailing environmental condition (Thomas and Hendricks 1956). The effects of pollutants may be synergistic, additive or antagonistic depending upon environmental factors and the species involved (Tingey and Reinert 1975). These pollutants caused serious set backs to morphology and physiology of plants. Present study examines the morphological and physiological responses of Croton bonplandianum to pollutants emitted due to the coal burning in the thermal power plant.

\section{MATERIALS AND METHODS}

Croton bonplandianum Baill (Euphorbiaceae) is a weed plant. Recently antitumor properties from the twig extract of this plant have been observed (Islam et al. 2010). 
The Badarpur thermal power plant (BTPP) located in South Delhi at the Delhi- Haryana border, at $77^{\circ} 22^{\prime} \mathrm{E}$ longitude and $28^{\circ} 25^{\prime} \mathrm{N}$ latitude, and $220 \mathrm{~m}$ above sea level, consumes about 10,439 metric tonnes of sulphur rich bituminous coal per day and generates 720 megawatt electricity. The emissions from coal consumption mainly include oxides of sulphur, nitrogen and carbon and particulate matters and other gaseous pollutants in minor quantities (Fig. 1).

Ten matured plants of Croton bonplandianum were collected randomly each from the polluted site (near Badarpur Thermal Power Plant Station) and the reference site (Hamdard University campus) located on Badarpur-Mehrauli road at 10 $\mathrm{km}$ west from the power station. Soils are saline and alkaline, and have similar composition at both sites.

The length as well as dry weight of root and shoot, leaf number and leaf area were observed in both the sites of sample. The leaf area was measured by a LI-3000A Leaf area meter (Li-cor, Lincoln, USA) and biomass by oven drying of samples at $80^{\circ} \mathrm{C}$. The chlorophyll and carotenoid contents of fresh leaves were estimated by the method of Hiscox and Israelstam (1979) using dimetyhl sulfoxide (DMSO) and by applying the formulae of MacLachlan and Zalik (1963), and Duxbury and Yentsch (1956). Stomatal conductance, intercellular $\mathrm{CO}_{2}$ concentration and net photosynthetic rate were measured by Infra Red Gas Analyser (LI 6200 portable photosynthesis system). Leaf gas exchange measurement were made on cloud-free days between 8.00-9.00 a.m. The level of significance of the variations observed was determined by the student ' $\mathrm{t}$ ' test.

\section{RESULTS AND DISCUSSION}

The data indicate that the population of $C$. bonplandianum growing in the vicinity of the power plant face a significant serious set back in their over all growth parameters studied (Table 1). Shoot length was more significantly affected (42\%) than root length $(17 \%)$.

The poor growth of $C$. bonplandianum could be due to translocation of $\mathrm{SO}_{2}$ to meristematic region (Crittender and Read 1978). $\mathrm{SO}_{2}$ may possibly slow down the rates of division and expansion of cells (Chang and Thompson 1966), leading to higher percent reduction in shoot length than root length. Root biomass showed a greater loss $(85 \%)$ in comparison to shoot biomass $(25 \%)$ and total biomass (54\%). Greater loss in root biomass probably due to inhibition in translocation of photosynthates (Tingey et al. 1971, 1973, 1976, Shimizu et al. 1980) causing a remarkable reduction $(82 \%)$ in root shoot ratio. Okano et al. (1984a,b) suggested that some gaseous pollutants alone and in combination can alter the normal allocation of dry matter within the plants and thus leaf growth is often favored at the expense of root growth. C. bonplandianum also exhibited a significant reduction in leaf number $(11 \%)$, area leaf $^{-1}(49 \%)$ and total leaf area $(54 \%)$ in the polluted sites compare to control. Reduction in growth and development of root, shoot and leaf under the coal smoke-pollutants were also observed by earlier workers on Solanum nigrum (Ghouse and Khan 1984), Gomphrena celosioides (Khan and Khair 1985), Melilotus indicus (Ghouse and Saquib 1986), Gnaphalium pensylvanicum (Malabari et al. 1991), Anagallis arvensis (Saquib et al. 1992), Brassica juncea (Saquib and Khan 1999), Datura innoxia (Husen et al. 1999).

The net photosynthetic rate in leaves of $C$. bonplandianum decreased significantly by over $64 \%$ to control (Table 2). Reduction in photosynthesis due to coal smoke pollution is not unusual (Wali et al. 1997, Nighat et al. 1999, 2000). Ziegler (1972) has observed inhibition of photosynthesis by $\mathrm{SO}_{3}^{-2}$ due to competition 
between $\mathrm{CO}_{2}$ and $\mathrm{SO}_{3}{ }^{-2}$ for active sites on ribulose 1, 5-diphosphate carboxylase, the key enzyme for photosynthetic $\mathrm{CO}_{2}$ fixation. A higher concentration of $\mathrm{SO}_{3}^{-2}$ resulted in non competitive inhibition of the enzyme. White et al. (1974) have observed inhibition of net photosynthesis in Medicago sativa exposed to $\mathrm{SO}_{2}$ concentration greater than $0.2 \mathrm{ppm}$. The net photosynthesis was significantly reduced in Pisum sativum plant exposed to 0.025 ppm $\mathrm{SO}_{2}$ (Bull and Mansfield
1974) and Vicia faba plant exposed to $0.035 \mathrm{ppm}$ $\mathrm{SO}_{2}$ (Black and Unsworth 1979). The decline in net photosynthetic rate due to pollutants may be via damage to the intersystem electron transport (Ishibashi et al. 1997) or decrease in PEP activity and concentration as a result of hydrolysis and mobilization from leaves (Joshi et al. 1993). Reduction in leaf areas could be also an additional factor contributing to the decline in net photosynthesis rate per plant (Table 2).

Table 1. Comparative data on morphological parameters obtained from the normal and polluted sample of Croton bonplandianum.

\begin{tabular}{|l|c|c|c|}
\hline Parameters & $\begin{array}{c}\text { Control } \\
\text { Mean } \pm \text { SD }\end{array}$ & $\begin{array}{c}\text { Polluted } \\
\text { Mean } \pm \text { SD }\end{array}$ & Percent Variation \\
\hline Root Length $(\mathrm{cm})$ & $17.60 \pm 2.70$ & $14.63 \pm 3.07$ & $-17^{*}$ \\
Shoot length (cm) & $44.10 \pm 11.20$ & $25.50 \pm 4.60$ & $-42^{* *}$ \\
Leaf Number Plant $^{-1}$ & $132.80 \pm 14.70$ & $118.0 \pm 8.95$ & $-11^{*}$ \\
Area Leaf ${ }^{-1}\left(\mathrm{~cm}^{2}\right)$ & $10.20 \pm 1.70$ & $5.17 \pm 0.75$ & $-49^{* *}$ \\
Total Leaf Area Plant ${ }^{-1}\left(\mathrm{~cm}^{2}\right)$ & $1340.5 \pm 205.0$ & $611.6 \pm 85.89$ & $-54^{* *}$ \\
Root Biomass (gm) & $2.81 \pm 1.10$ & $0.43 \pm 0.08$ & $-85^{* *}$ \\
Shoot Biomass (gm) & $5.53 \pm 1.17$ & $4.15 \pm 0.47$ & $-25^{* *}$ \\
Total Biomass (gm) & $8.34 \pm 0.91$ & $5.53 \pm 1.17$ & $-45^{* *}$ \\
Root Shoot Ratio & $0.57 \pm 0.26$ & $0.10 \pm 0.02$ & $-82^{* * *}$ \\
\hline
\end{tabular}

Mean \pm Standard Deviation **Significant $(\mathrm{P}<0.01) *$ Significant $(\mathrm{P}<0.05)$. Above data have been reduced to two decimal place after final calculations.

Table 2. Comparative data on physiogical parameters obtained from the normal and polluted sample of Croton bonplandianum.

\begin{tabular}{|c|c|c|c|}
\hline Parameters & $\begin{array}{c}\text { Control } \\
\text { Mean } \pm \text { SD }\end{array}$ & $\begin{array}{c}\text { Polluted } \\
\text { Mean } \pm \text { SD }\end{array}$ & Percent Variation \\
\hline Net Photo Synthetic Rate $\left(\mu \mathrm{mol} \mathrm{CO} \mathrm{CO}^{-2} \mathrm{~s}^{-1)}\right.$ & $7.56 \pm 2.0$ & $2.69 \pm 1.5$ & -64 \\
\hline Intercellular $\mathrm{CO}_{2}$ concentration (ppm) & $450.25 \pm 35.50$ & $369.15 \pm 32.20$ & -18 \\
\hline Stomatal Conductance $\left(\mu \mathrm{mol} \mathrm{m} \mathrm{m}^{-2} \mathrm{~s}^{-1)}\right.$ & $0.72 \pm 0.06$ & $0.22 \pm 0.02$ & -69 \\
\hline Chlorophyll a ( $\mathrm{mg} \mathrm{g}^{-1}$ fresh wt) & $1.61 \pm .0 .02$ & $0.17 \pm 0.04$ & -89 \\
\hline Chlorophyll b (mg g ${ }^{-1}$ fresh wt) & $1.48 \pm 0.22$ & $0.37 \pm 0.09$ & -74 \\
\hline Total Chlorophyll (mg g ${ }^{-1}$ fresh wt) & $3.09 \pm 0.20$ & $0.54 \pm 0.12$ & -83 \\
\hline Carotenoids ( $\mathrm{mg} \mathrm{g}^{-1}$ fresh wt) & $0.98 \pm 0.02$ & $0.78 \pm 0.1$ & -20 \\
\hline
\end{tabular}

Mean \pm Standard Deviation **Significant $(\mathrm{P}<0.01)$. Above data have been reduced to two decimal place after final calculations. 


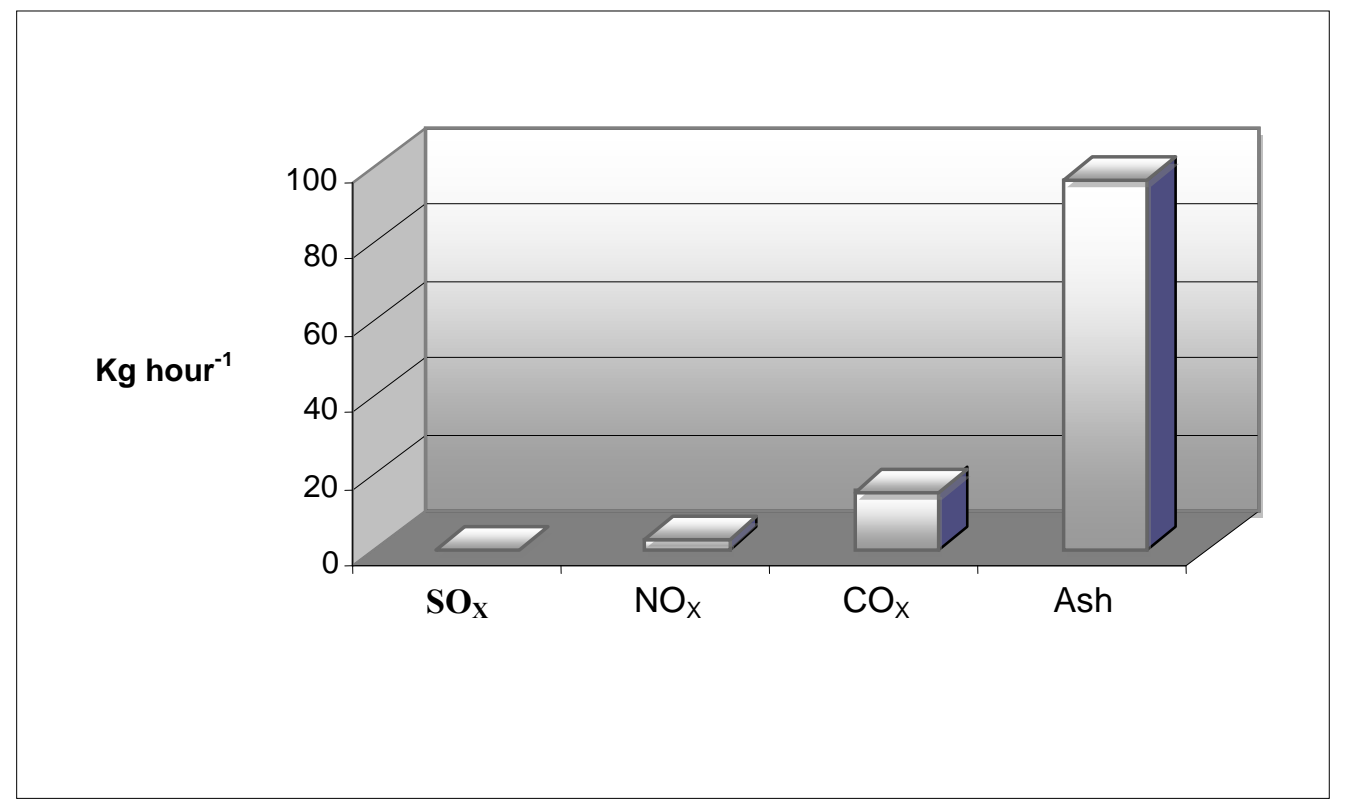

Fig. 1. Emission Rate of Pollutants. $\mathrm{SO}_{\mathrm{X}}=$ Oxide of Sulphur, $\mathrm{NO}_{\mathrm{X}}=$ Oxide of Nitrogen, $\mathrm{CO}_{\mathrm{X}}=$ Oxide of Carbon in $10^{5} \mathrm{Kg}$ hour ${ }^{-1}$, and emission rate of ash in $10^{3} \mathrm{Kg}_{\text {hour }}{ }^{-1}$ from the Thermal Power Plant. (Courtesy of Badarpur Thermal Power Plant, New Delhi).

Stomatal conductance and intercellular $\mathrm{CO}_{2}$ concentration also decrease in plant exposed to BTPP pollution, the extent of decline being $69 \%$ and $18 \%$, respectively (Table 2 ). An increase in the atmospheric $\mathrm{CO}_{2}$ shifts the activity of ribulose 1,5biphosphate carboxilase and oxygenase (Ribisco) in favor of carboxilation (Bowes 1991, Stitt 1991). Very high concentration of atmospheric $\mathrm{CO}_{2}$ may depress the stomatal conductance (Morrison 1987, Field et al. 1995) which decrease the internal $\mathrm{CO}_{2}$ concentration in leaves, thus causing a decrease in the net photosynthesis (Carison 1983, Bazzaz 1990). The photosynthetic activity also depends on pigment content. The pigment content including chlorophyll a, chlorophyll $\mathrm{b}$, total chlorophyll and carotenoids decreased significantly in the polluted sample with percent variation having $89 \%, 74 \%$, $83 \%$ and $20 \%$, respectively (Table 1 ). The lower amount of chlorophyll a, chlorophyll b, total chlorophyll and carotenoids under the stressed environment were also noted in several other species (Singh et al. 1985, Singh et al. 1990, Malabari et al. 1991, Dhir et al. 1999, Nighat et al. 1999, 2000, Saquib 2008, Iqbal et al. 2010). In the present study Chlorophyll a was found to be more severely affected than chlorophyll b. Sulphite may react with chlorophyll to produce superoxide radicals (Shimazaki et al. 1980, William and Banerjee 1995). Chlorophyll a is degraded to pheophytin through replacement of $\mathrm{mg}^{+2}$ ions from chlorophyll molecules, but degradation of chlorophyll $\mathrm{b}$ by $\mathrm{SO}_{2}$ leads the formation of chlorophyllide $b$ due to removal of phytol group of the chlorophyll b molecules (Rao and Le Blank 1966). The sensitivity of chlorophyll a to air pollution is four and half times higher than carotenoides. The same results were also observed in Calendula officinalis (Singh et al. 1985) and Dahlia rosea (Ahmad et al. 1988) under the stress of $\mathrm{SO}_{2}$. 


\section{REFERENCES}

Ahmad, K.J., M. Yunus, S.N. Singh, K. Shrivastava, N. Singh and K. Kulshreshtha. 1988. Survey of Indian plants in relation to atmospheric pollution: A Research Report In: Perspectives in Environmental Botany, Vol. 2. (eds.) Rao. D.N., K.J. Ahamad, M. Yunus and S.N. Singh. Today and Tomorrow's Printer and Publishers, New Delhi, India, pp. 283-306.

Bazzaz, F.A. 1990. The response of natural ecosystems to the rising global $\mathrm{CO}_{2}$ levels. Annu. Rev. Ecol. Syst. 21:167-196.

Black, V.J. and M.H. Unsworth. 1979. Effect of low concentration of $\mathrm{SO}_{2}$ on net photosynthesis and dark respiration of Vicia faba L.J. Expt. Bot. 30:473-483.

Bowes, G. 1991. Growth at elevated $\mathrm{CO}_{2}$ : Photosynthetic responses mediated through Rubisco. Plant Cell Environ. 14:795-806.

Bull, J.N. and T.A. Mansfield. 1974. Photosynthesis in leaves exposed to $\mathrm{SO}_{2}$ and $\mathrm{NO}_{2}$. Nature 250:443.

Carison, R.W. 1983. The effect of $\mathrm{SO}_{2}$ on photosynthesis and leaf resistance at varying concentration of $\mathrm{CO}_{2}$. Environ Pollution 3:309321.

Chang, C.W. and C.R. Thompson. 1966. Site of fluoride accumulation in novel orange leaves. Plant Physiol. 41:211-213.

Crittenden, P.D. and D.J. Read. 1978. The effect of air pollution on plant growth with special reference to $\mathrm{SO}_{2}$. II. Growth studies with Lolium perenne L. New Phytol. 80:49-62.

Dhir, B., M.P. Sharma, Mahmooduzzafar and M. Iqbal. 1999. Form and function of Achyranthes aspera Linn. under air pollution stress. $J$. Environ. Biol. 20:19-23.
Duxbury, A.C. and C.S. Yentsch. 1956. Plankton pigment nomography. J. Air Pollut. Contr. Assoc. 16:145-150.

Field, C.B., R.B. Jackson and H.A. Mooney. 1995. Stomatal responses to increased $\mathrm{CO}_{2}$ : Implications from the plant to the global scale. Plant Cell Environ. 18:1214-1225.

Ghouse, A.K.M. and M. Saquib. 1986. Growth responses of some weeds of an agroecosystem to air pollution. Acta Bot. Indica 14(Spl.):234235.

Ghouse. A.K.M. and F.A. Khan. 1984. Effect of air pollutants on the growth responses of Solanum nigrum L. Acta Bot. Indica 12:93-94.

Hiscox, J.D. and G.F. Israelstam. 1979. A method for the extraction of chlorophyll from leaf tissue without maceration. Can. J. Bot. 57:1332-1334.

Husen, A., S.T. Ali, Mahmooduzzafar and M. Iqbal. 1999. Structural, functional and biochemical responses of Datura innoxia Mill. Coal-smoke pollution. Proc. Acad. Environ. Biol. 8:61-72.

Iqbal, M., Mahmooduzzafar, F. Nighat and P.R. Khan. 2010. Photosynthetic, metabolic and growth responses of Triumfetta rhomboidea to coal-smoke pollution at different stages of plant ontogeny. J. Plant Interactions 5:11-19.

Iqbal, M., P.S. Srivastava and T.O. Siddiqi. 2000. Anthropogenic stresses in the environment and their consequences. In: Environmental Hazards: Plants and People. (eds.) Iqbal, M., P.S. Srivastava and T.O. Siddiqi. CBS Publishers, New Delhi, pp. 1-37.

Ishibashi, M., K. Sonoike and A. Watanabe. 1997. Photo-inhibition of photosynthesis during the rain treatment: intersystem electron transfer as the site of inhibition. Plant Cell Physiol. 38:96146. 
Islam, M.S., M.M. Rahman, M.A. Rahman, M.A. Qayum and M.F. Alam. 2010. In: vitro evaluation of Croton bonplandianum Baill. as potential antitumor properties using Agrobacterium tumefaciens. J. Agr. Technol. 6:79-86.

Joshi, U.N., S.K. Arora and Y.P. Luthra. 1993. $\mathrm{SO}_{2}$ induced changes in $\mathrm{CO}_{2}$ fixation and photosynthetic pigments in Sorghum bicolor leaves. Ann. Biol. 9:102-108.

Khan, F.A. and S. Khair. 1985. A note on the responses of Gompherena celosioides Mart. to air pollutants emerging out of coal burning, Geobios 12:88-89.

MacLachlan, S. and S. Zalik. 1963. Plastid structure, chlorophyll concentration and free amino acid composition of a chlorophyll mutant of barley. Can. J. Bot. 41:1053-1060.

Malabari, A.A., Z. Ahmad and M. Saquib. 1991. Effect of air pollution on Gnephalium pensylvanicum willd-a cropland weed. Geobios 18:7-10.

Morrison, J.I.L. 1987. Intercellular $\mathrm{CO}_{2}$ concentration and stomatal responses to $\mathrm{CO}_{2}$ In: Stomatal Function. (eds.) Zieger, E., G.D. Farquhar and I.R. Cowen. Stanford University Press, Stanford, CA, pp. 229-251.

Nighat, F., Mahmooduzzafar and M. Iqbal. 1999. Foliar responses of Peristrophe bicalyculata to coal smoke pollution. J. Plant Biol. 42:205212.

Nighat, F., Mahmooduzzafar M. Iqbal. 2000. Stomatal conductance, photosynthetic rate and pigment content in Ruellia tuberose leaves as affected by coal-smoke pollution. Biol. Plant 43:263-267.

Okano, K., O. Ito, G. Takeba, A. Shimizu and T. Totsuka. 1984a. Effect of $\mathrm{NO}_{2}$ and $\mathrm{O}_{3}$ alone or

ECOPRINT VOL 17, 2010 in combination on kidney bean plants. IV. Alteration of $\mathrm{C}^{13}$ - assimilate partitioning induced by ozone. Res. Rep. Natl. Inst. Environ. Stud. 66:39-48.

Okano, K., O. Ito, G. Takeba, A. Shimizu and T. Totsuka. 1984b. Effect of $\mathrm{NO}_{2}$ and $\mathrm{O}_{3}$ alone or in combination on kidney bean plants. V. $\mathrm{C}^{13}$ assimilate partitioning as effected by $\mathrm{NO}_{2}$ and/ or $\mathrm{O}_{3}$. Res. Rep. Natl. Inst. Environ. Stud. 66:49-57.

Rao, D.N. and F. Le Blanc. 1966. Effect of sulphur dioxide pollution on the lichen algae, with special reference to chlorophyll. Bryologist 69:69-65.

Saquib, M. 2008. Effect of coal smoke pollution on the biomass and chlorophyll pigments of Brassica juncea. Ecoprint 15:1-6.

Saquib, M. 2009. Root growth responses of Melilotus indicus (L.) All. to air pollution. Ecoprint 16:29-34.

Saquib, M. and F.A. Khan. 1999. Air pollution impacts on the growth and reproductive behaviour of mustard. J. Environ. Biol. 20:107110.

Saquib, M., Z. Ahmad, A. Zaheer, and A.A. Malabari. 1992. Impact of air pollution on some weeds of tropical agro-ecosystem. J. Environ. Biol. 13:145-149.

Shimazaki. K.I., T. Sakaki, D. Kondo and K. Sugahara. 1980. Active $\mathrm{O}_{2}$ participation in chlorophyll destruction and lipid peroxidation in $\mathrm{SO}_{2}$ fumigated leaves of spinach. Plant Cell Physiol. 21:1193-1204.

Shimizu, H., A. Firukawa and T. Totsuka. 1980. Effects of low concentrations of $\mathrm{SO}_{2}$ on the growth of sunflower plants. Environ. Control in Biol. 18:39-47.

Singh, S.N., M. Yunus and N. Singh. 1990. Effect of sodium metabisulphite on chlorophyll, 
protein and nitrate reductase activity of tomato. Sci. Total Environ. 81:269-274.

Singh, S.N., M. Yunus, K. Srivastava, K. Kulshreshtha and K.J. Ahmad. 1985. Response of Calendula officinalis $\mathrm{L}$ to long-term fumigation with $\mathrm{SO}_{2}$. Env. Pollution 39:17-25.

Stitt, M. 1991. Rising $\mathrm{CO}_{2}$ levels and their potential significance for carbon flow in photosynthetic cell. Plant Cell Environ. 14:741-762.

Thomas, M.D. and R.H. Hendricks. 1956. Effect of air pollution on plants. In: Air Pollution Hand Book. (eds.) Magil, P.L., F.R. Holden and C. Ackley. McGraw-Hill Book Company, New York, Toronto, London.

Tingey, D.T. and R.A. Reinert. 1975. The effect of ozone and sulphur dioxide singly and in combination on plant growth. Environ. Pollution 9:117-125.

Tingey, D.T., R.A. Rienert, C. Wickliff and W.W. Heck. 1973: Chronic ozone or sulphur dioxide exposures, or both, affect the early vegetative growth of soybean. Can. J. Plant Sci. 53:875879.

Tingey, D.T., R.G. Wilhour and C. Standley. 1976. The effect of chronic ozone exposures on the metabolite content of ponderosa pine seedlings. For. Sci. 22:234-241.

Tingey, D.T., W.W. Heck and R.A. Reinert. 1971. Effect of low concentration of ozone and sulpfur dioxide on foliage, growth and yield of radish. J. Amer. Soc. Hort. Sci. 96:369-371.

Wali, B., J. Ahmad, Mahmooduzzafar and M. Iqbal. 1997. Responses of Sida actua L. to coal smoke pollution. Chem. Environ. Res. 6:171179.

White, K.L., A.C. Hill and J.H. Bennett. 1974. Synergistic inhibition of apparent photosynthesis rate of alfa-alfa by combination of $\mathrm{SO}_{2}$ And $\mathrm{NO}_{2}$. Environ. Sci. Technol. 8:574576.

Williams, A.J. and S.K. Banerjee. 1995. Effect of thermal power plant emissions on the metabolic activities of Mangifera indica and Shorea robusta. Environ. Ecol. 13:914-919.

Yunus, M. and M. Iqbal (ed.). 1996. Plant Responses to Air Pollution. John Wiley, Chichester.

Ziegler, I. 1972. The effect of $\mathrm{SO}_{3}^{-2}$ on the activity of ribulose 1,5-diphospate carboxilase in isolated spinach chloroplast. Planta 103:155163. 